\title{
The application of the RT-PCR method for the staging of the prostate cancer progression
}

\author{
Anezka Zummerova ${ }^{1}$, Peter Labas ${ }^{2}$, Daniel Bohmer ${ }^{3}$, Milan Blasko ${ }^{4}$, Stefan Polak ${ }^{5}$, Lubos \\ Danisovic ${ }^{3}$ and Vanda Repiska ${ }^{3}$ \\ ${ }^{1}$ Department of Pathology and Forensic Medicine, Health Care Surveillance Authority, Antolska 11, Bratislava, Slovakia \\ ${ }^{2}$ First Department of Surgery, Faculty of Medicine, Comenius University, Mickiewiczova 13, Bratislava, Slovakia \\ ${ }^{3}$ Institute of Medical Biology, Genetics and Clinical Genetics, Faculty of Medicine, Comenius University, Sasinkova 4, \\ Bratislava, Slovakia \\ ${ }^{4}$ Department of Urology, Faculty of Medicine, Comenius University, Limbova 5, Bratislava, Slovakia \\ ${ }^{5}$ Institute of Histology and Embryology, Faculty of Medicine, Comenius University, Sasinkova 4, Bratislava, Slovakia
}

\begin{abstract}
Molecular biology seems to bring more convincing markers for the detection of prostate cancer as well as the development of metastases than immunohistochemistry. The main goal of present work was to detect the expression of prostate specific antigen (PSA) and prostate-specific membrane antigen (PSM) genes in the micrometastases by the RT-PCR to assess the progression of prostate cancer. We analyzed 50 patients: 28 patients with clinically localized or locally advanced prostate cancer who underwent radical prostatectomy, 7 patients with clinically proven metastases, 8 patients with benign prostatic hyperplasia, and 7 healthy young men. The results of RT-PCR in the first group of 28 patients varied, however, they were in good correlation with the health status of the patients. Positive results of PSA and notably for PSM were good predictors of beginning metastasing process. Seven patients with metastatic disease had positive RT-PCR results both for PSA and PSM. All of the patients with benign prostatic hyperplasia and healthy young men had negative RT-PCR results for PSA and PSM. The study showed that positive RT-PCR results for PSA and especially for PSM correlated well with the progression of the disease and negative results reflected good health status of the patients.
\end{abstract}

Key words: Prostate cancer - Micrometastases - RT-PCR - Prostate specific antigen - Prostate specific membrane antigen

\section{Introduction}

Prostate cancer is now recognized as one of the most important medical problems facing the male population. In Europe, prostate cancer is the most common solid neoplasm, with an incidence rate of 214 cases per 1000 men, outnumbering lung and colorectal cancer (Boyle and Ferlay 2005). Furthermore, prostate cancer is currently the second most common cause of cancer death in men (Jemal et al. 2008). It is predominantly a disease of older males, with a peak incidence after the age of

Correspondence to: Anezka Zummerova, Department of Pathology and Forensic Medicine, Health Care Surveillance Authority, Antolska 11, 85107 Bratislava, Slovakia

E-mail: anezkazummerova@gmail.com
50 (Fletcher 2007). Therefore, it is a bigger health concern in developed countries with their greater proportion of elderly men (Parkin et al. 2001). There are still many unanswered questions about the prostate cancer, and that is the reason why prostate gland carcinoma belongs to one of the most studied malignant diseases.

This disease is characterized by a wide range of clinical, pathological, histological, genetic, and molecular features regarding specific treatment and monitoring. Sometimes it is even clinically silent for many years (occult carcinoma) and diagnosed when progressive metastatic process has began (Kumar et al. 2007). The biggest attention today is dedicated to the detection of the disease at the earliest possible stage, the assessment whether the cancer is significant or non-significant, and last but not least the staging of the progression 
of the disease and the selection of appropriate therapy. This is especially difficult since the symptoms of prostate cancer and the rapidity of the progression of the disease can vary greatly from patient to patient. In some men, prostate cancer is life threatening, while in many others, it can exist many years without causing health problems (Rubin and Strayer 2007). Standardly used prognostic parameters of prostate cancer, as the determination of the extent of the disease (staging), the degree of glandular differentiation (grading, Gleason score), prostate specific antigen (PSA) and its dynamics in blood seem to be insufficient in the prediction of the behaviour of the disease in many cases (Haas et al. 2005; Zhang et al. 2008). The tendentious to impose molecular-genetic methods to assess the degree of the progression of the disease grow stronger; especially, for the detection of the early metastatic process. Seeking for new parameters enabling better prediction of the biological behavior of the tumor is the only way that leads to improved and individualized approach to the treatment of particular patients.

We attempted to do one of the first analyses of chosen markers in Slovak republic. We introduced nested Reverse transcriptase-polymerase chain reaction (RT-PCR) for the detection of circulating tumor cells, so called micrometastases, in the peripheral blood of patients with prostate cancer. This method is being used in many countries for the assessment of the progression of mammary cancer, renal cell carcinoma, or bladder cancer. The other goal of the present study was to verify the reliability of this approach. During 5 -year study we used a group of 28 patients with verified diagnosis of localized or locally advanced prostate cancer who underwent radical prostatectomy, and our ambition was to check the correlation between the presence of the circulating tumor cells in peripheral blood of these patients and the clinical stage of the disease.

\section{Materials and Methods}

During the five-year period, from 2004 to 2009, we studied a group of 28 patients with localized or locally advanced prostate cancer in the age between 50 and 80 . In analyzed patients no metastases were diagnosed by standardly used clinical methods. These patients underwent radical prostatectomy and their health status was regularly monitored, especially by the detection of PSA level in their blood. The levels of PSA antigen in these patients were measured before radical prostatectomy, proximately after the operation, one year after the operation, and two years after the operation. Nested RT-PCR method was used to detect possible micrometastases in peripheral blood of these patients. These patients with localized or locally advanced prostate cancer were diagnosed by RT-PCR method before they underwent radical prostatectomy and two years after the operation.
Peripheral blood of healthy young women in age between 18 and 24 was used as a negative control. The malignant tissue obtained from prostate gland was used as a positive control. Then we examined 7 patients with clinically diagnosed metastases of prostate cancer, 8 patients with benign prostatic hyperplasia, and seven healthy young men using RT-PCR method. Informed consent was obtained from all of the studied subjects.

The first step of our work was the isolation of cell elements from the peripheral blood. The second step was the isolation of RNA. Then the RT-PCR method was used to transcript the RNA to the complementary DNA (cDNA) and its subsequent multiplication. Primers that bound to the RNA sequences complementary to a short section of PSA (prostate-specific antigen) and PSM (prostate-specific membrane antigen) gene were used in this step. However, these primers were not specific enough. In order to avoid this problem, we applied nested PCR, using primers complementary to sequences that were nowhere else in the genome. To realize our study we had to determine the sequence of primers, establish suitable algorithm of programs for our thermal cycler, and modify all of the reactions according to our laboratory conditions.

The acquisition of sufficient amount of cell elements from peripheral blood was an unavoidable step before follow-up analysis. The isolation was assured by the sedimentation reagent Ficoll-Paque Plus (Amersham Pharmacia Biotech, UK). We collected $6 \mathrm{ml}$ of peripheral blood from all of the patients and isolated cell fraction from it. Prostatic epithelial cells were suspected to be part of this cell fraction.

The whole RNA was isolated from cells by using Trizol reagent (Gibco, USA), following the method published by Baffa et al. (1996). Supernatant with the RNA was then transferred into another test-tube, and isopropanol was used to precipitate RNA. GAPDH (glyceraldehyde-3-phosphate dehydrogenase) was used as an internal control to assess mRNA integrity (GAPDH forward primer: TCTGCCCCCTCTGCTGATGC and GAPDH reverse primer: CCACCACCCTGTTGCTGTAG).

The Platinum Quantitative RT-PCR Thermoscript OneStep System (Invitrogen, USA) was used for the RT-PCR (Brawer et al. 1992). Primers used for the analysis of PSA system were PSA forward primer: CGGAAGTGGATCAAGGACA and PSA reverse primer: AACGTGATGATA - 16XTV. For the analysis of PSM system the following pair of primers was used: PSM forward primer GGGAGTCATTCCCAGGAATT and PSM reverse primer: AACGTGATGATA - 16XTV.

RT-PCR was performed at thermal cycler PTC ${ }^{100}$ Programmable Thermal Controller (MJ Research Inc., USA) according to algorithm published earlier (Katz et al. 1994). The products of the reaction were $741 \mathrm{bp}$ PSA and $630 \mathrm{bp}$ PSM. 
The products of the former RT-PCR reaction served as a substance for nested PCR reaction, which was performed according to Repiská et al. (2005). In the nested PCR technique, the amplified DNA was used as a template for another set of inner primers for selective amplification of shorter DNA sequences. One of each pair of primers for nested PSA or nested PSM system was used. N PSA forward primer: TTGGAACCTTGGAAATGAC, N PSA reverse primer: GACAACCCATCCTATCTGTG, N PSM forward primer: GTGGACCCTTCCAAGGC and N PSM reverse primer: GACATACCACACAAATTCAATACGG. After the rough mixing of all of the components of nested PCR reaction, short centrifugation was realized. The products of the nested PCR procedure were $231 \mathrm{bp}$ PSA and $142 \mathrm{bp}$ PSM. Agarose gel electrophoresis was used for the detection of PCR product.

\section{Results}

The results of our study and their comparison with usually studied parameters are shown in the Table 1. Nine out of twenty-eight patients with localized or locally advanced prostate cancer examined by the RT-PCR method before they underwent radical prostatectomy showed positive result both for PSA and PSM. Six of these patients showed positive RTPCR reaction for PSA and PSM also two years after surgical operation. Their health status worsened, metastases occurred in a short time and 4 of them already died up to this date. One of the nine patients, who had positive RT-PCR results for PSA and PSM before operation, had negative results of RT-PCR reaction both for PSA and for PSM two years after the operation. His health status shows no progression of the disease. The last two of the nine patients with positive PSA and PSM results before radical prostatectomy had negative result for PSA and positive result for PSM using RT-PCR method two years after the operation. They show the progression of the disease in means of metastases in bones.

Six out of twenty-eight patients had negative result for PSA and positive result for PSM using RT-PCR reaction before radical prostatectomy. Independently to the results of RT-PCR for PSA after the operation, five of these patients had positive results for PSM also two years after the operation and one of these five patients have already died and in two patients metastases have developed. The last out of the six patients had negative result of RT-PCR for PSM two years after the operation. In this patient no metastases were diagnosed. We assume that RT-PCR for PSM has better predicting value of the progression of the disease than RT-PCR for PSA. The remaining two of the patients with positive RT-PCR result for PSM after the operation have not experienced health problems up this time; however, we suggest that continuous monitoring is especially important in these patients.
Finally, thirteen out of twenty-eight patients with localized or locally advanced prostate cancer had negative results of RT-PCR for PSA and also for PSM before the operation. Nine of them had negative result for PSA and negative result for PSM also two years after the operation, and two of them had positive result for PSA and negative result for PSM after the operation. The health conditions of all of these eleven patients are still very good; they show no progression of the disease. The last two of the thirteen patients had negative result for PSA and positive result for PSM two years after the operation and their health status is getting worse, the disease is progressing, and metastases in bones and in some other organs appeared too. This may also speak for better sensitivity of RT-PCR for PSM.

Then we diagnosed seven patients with clinically diagnosed metastases of prostate cancer. RT-PCR reaction for PSA and also RT-PCR reaction for PSM was positive in all of these patients. The results of RT-PCR reaction of the eight patients with benign prostatic hyperplasia were negative both for PSA and PSM. Likewise, RT-PCR reaction of the seven healthy young men was negative for both parameters.

For better evaluation of the relevance of RT-PCR reaction in prediction of the progression of prostate cancer, we have made some statistical analysis. In 28 patients with clinically localized or locally advanced prostate cancer, we correlated pre-operative and then post-operative RT-PCR results with final health conditions of the patients. First, we evaluated the predicting role of RT-PCR for PSA and for PSM separately, and then we evaluated its role when considering the two parameters together. The results are presented in the Tables A1-A6 (see Appendix). Seeing Tables A1-A6 and supplementary Chi-Square Tests, especially Fisher's exact test, we can observe good significance of predicting value of RT-PCR reaction, both for PSA and notably for PSM. Preoperative PSA RT-PCR had an odd ratio of 22.4 (95\% confidence interval, 2.2-227; $p=0.04$ ) and preoperative PSM RT-PCR had an odd ratio of 15.12 (95\% confidence interval, $2.3-100 ; p=$ 0.03 ) in predicting the progression of the disease.

We also evaluated the significance of PSA antigen, standardly used prognostic parameter. Since all of the patients had PSA values higher than upper limit of normal $(4.0 \mathrm{ng} / \mathrm{ml})$ before undergoing radical prostatectomy, we correlated the values of PSA antigen in blood one year and two years after the operation with health conditions of the 28 patients. The value $0.2 \mathrm{ng} / \mathrm{ml}$ of PSA antigen in blood in patients after radical prostatectomy was considered marginal, according to international consensus defining recurrent cancer (Boccon-Gibod et al. 2004; Moul 2000). The results proved significance of this prognostic parameter (see Table A7, A8 and supplementary Chi-Square Tests).

From these results we can see that RT-PCR reaction both for PSA and especially for PSM has significant prognostic value. Admittedly, additional analyses need to be done. 


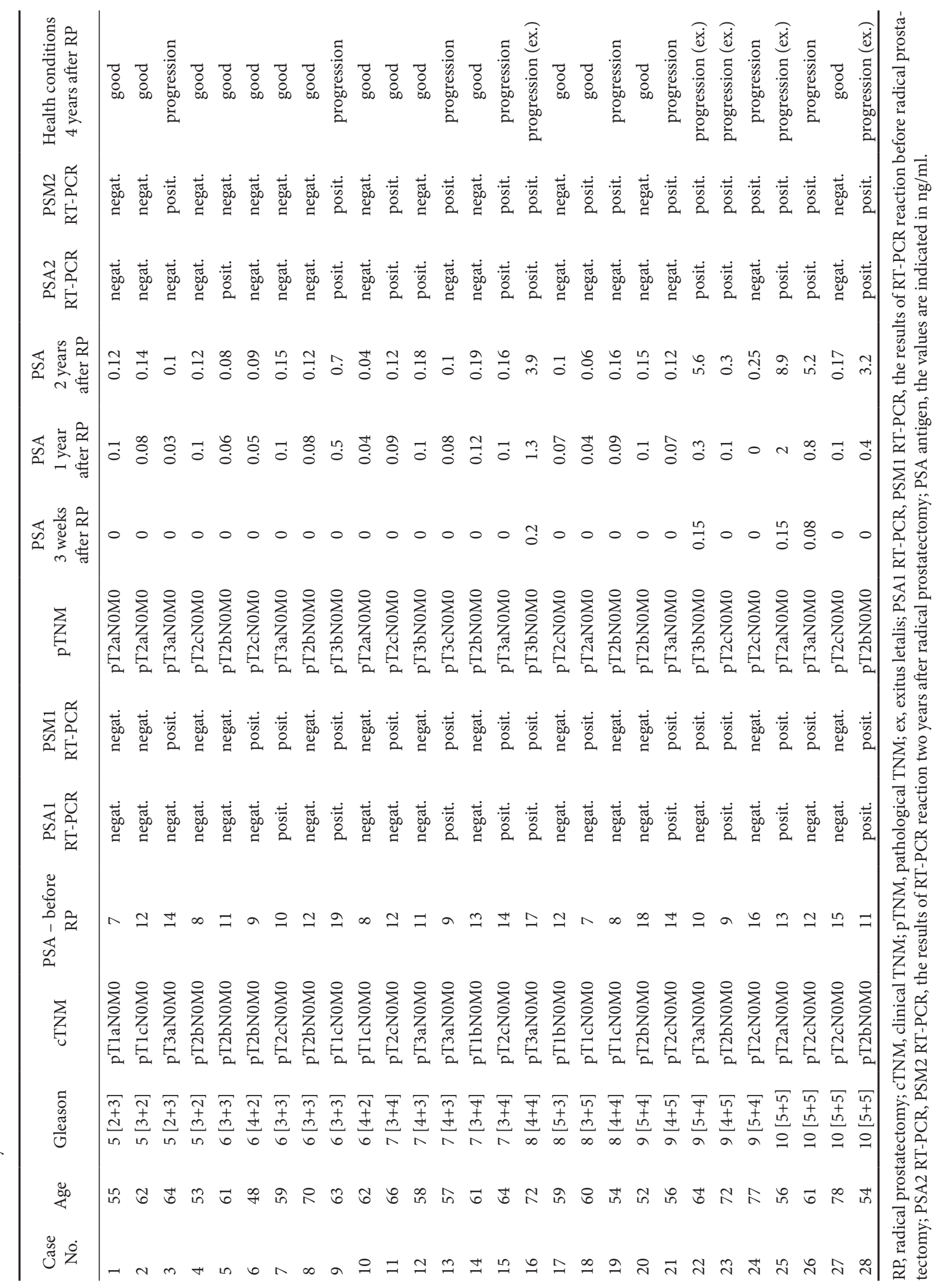


However, we assume that this method can greatly improve the choice of appropriate management of patients with prostate cancer, using and evaluating it together with up to now used prognostic parameters.

\section{Discussion}

Prostatic specific antigen, one of the most standardly used screening and prognostic parameters used by clinical patricians, has too many limitations. Traditionally, a PSA value of $4.0 \mathrm{ng} / \mathrm{ml}$ has been used as the upper limit of normal. The level of the PSA is usually higher in men with prostate cancer than in men without cancer (Chang et al. 2005). Cancer cells usually produce more PSA, however also any other conditions that disrupt the normal architecture of the prostate, including nodular hyperplasia, prostatitis, prostatolithiasis, may also cause an elevation in serum levels of PSA (Underwood and Cross 2009). Similarly, transrectal or transperineal biopsy of prostate, massage of prostate, cystoscopy, and transurethral resection of the prostate elevate the serum levels of PSA (Rubin and Farber 1999). Moreover, in a minority of cases of prostate cancers, especially those confined to the prostate, serum PSA levels are not elevated. In addition, the source of pathologically elevated production of PSA in prostate cancers and its bone metastases are most commonly well-differentiated adenocarcinoma structures in particular, and the production of the PSA in a general way diminishes with the decrease of the glandular differentiation (Kolombo et al. 2007). Finally, PSA was initially considered specific product of the prostatic tissue. However, it is not organ specific; by means of immunohistochemic methods minimal quantities were detected in malignant tissue of mammary gland, lungs, endometrium, and periurethral glands (Narita et al. 2005, 2008). Because of these restrictions in both specificity and sensitivity, PSA is of limited use when used as an isolated screening parameter for prostate cancer. Some better application of PSA screening seems to be in monitoring patients after radical prostatectomy, but there appear some limitations, too. Several refinements in the interpretation of PSA values have been introduced to further enhance its diagnostic utility. These include rate of changes of PSA values within time, especially PSA velocity and PSA doubling time, determination of the ratio between the serum PSA and volume of the prostate gland (PSA density), the measurement of free versus bound forms of circulating PSA (PSA ratio), and obviously age-specific PSA (Kataja and Bergh 2005).

The target of the molecular biology research is to find more persuasive markers of biological character of prostate cancer in individual patients that would be helpful in setting the stage of the disease and assessing an adequate strategy and aggressiveness of the treatment of these patients. The circulating tumor cells that can sometimes be detected in patients with prostate cancer are originally epithelial prostatic cells that are characterized by the expression of the genes for PSA and PSM (Altimari et al. 2008). It is suspected that their presence in the peripheral circulation of patients with prostate cancer can be helpful in predicting the progression of the disease. Normal immunological reaction of the human organism does not anticipate the survival of the non-malignant prostate cells in blood, so their presence in the circulation is regarded as one of the first steps in the cascade of metastasing process (Ghossein et al. 1995). The micrometastases are detectable by RT-PCR reaction, which is an extremely sensitive method. Experimental data indicate that RT-PCR can detect a single PSA/PSM expressing prostate cancer cell in up to 100 million other ambient cells in vitro. Using this method, one PSA/PSM positive cell can be detected in $5 \mathrm{ml}$ of peripheral blood. The presence of 1000 PSA/PSM expressing cells in peripheral circulation eventuates in the positive result of RT-PCR (Gala et al. 1998). Hence, the sensitivity of this method is high enough to detect smaller amount of circulating tumor cells than is needed for the formation of metastases. From the experiments made on laboratory animals, it is assessed that approximately 10000 circulating tumor cells in peripheral blood result in the formation of metastases. The result of the RT-PCR method in vivo thus depends on the ongoing process of the dissemination of tumor cells in circulation and on the efficiency of the immunological reactions of the organism in eliminating these micrometastases (Katz et al. 1994).

The results of our study showed that RT-PCR reaction for PSA and PSM correlates well with health status of patients. When we compare it with standard prognostic factors, such as Gleason score, staging by TNM classification and preoperative PSA serum level, we see a good correlation and we can say that this approach seems to have relevant prognostic value. In many cases, the detection of micrometastases in peripheral blood of patients using RT-PCR reaction even seems to have better predicting value of the extracapsular extention than monitoring the serum level of PSA. Positive RT-PCR reaction for both PSA and PSM in majority of cases meant progression of the disease and the formation of metastases. The patients with negative PSA and positive PSM prevailingly also showed the worsening of their health status. We noticed that patients with positive RT-PCR reaction for PSA and negative RT-PCR reaction for PSM showed no progression of the disease; their health conditions were optimal. From these results we can imply higher significance of RT-PCR for PSM than for PSA. Patients with negative RT-PCR reaction for PSA and also for PSM generally did not show any progression of the cancer. This means that at the time of the realization of RT-PCR reaction, they did not have detectable amount of epithelial prostate cells - micrometastases in peripheral blood. Obvi- 
ously, repetitive RT-PCR testing of the series of gradually taken blood samples has better clinical value.

Up to this time, much research has been done that proven a high sensitivity of RT-PCR reaction. Almost all of them have showed that RT-CR positive patients were at high risk for recurrence of prostate cancer after radical prostatectomy. It showed that RT-PCR reaction could be considered early staging modality for radical prostatectomy candidates. Other researches and detailed analyses need to be done to come to definite conclusions. Obviously, repetitive testing is one of the conditions. Nevertheless, researches that have been done up to this time show that RT-PCR method seems to be a commitment to future predictions.

\section{Conclusion}

To summarize, we can claim that by our study we confirmed a concord between the result of RT-PCR reaction and the clinical status of the disease. RT-PCR reaction can be used for the prediction of the progression of prostate cancer. In many cases, the detection of serum PSA levels seems to be less reliable than the detection of PSA/PSM encoding gene in circulating prostate cells by RT-PCR reaction. Obviously, continual monitoring of patients by RT-PCR reaction is essential for more accurate deductions. Searching for new parameters allowing better assessment of the biological behavior of the tumor is necessary for setting an appropriate strategy and aggressivity of the treatment of individual patients. Molecular biology plays a big role in this. RT-PCR reaction and the detection of circulating tumor cells in peripheral circulation of patients with prostate cancer seem to be a step forward. However, the impact of this technique in the management of patients with prostate cancer requires continued investigation.

Acknowledgement. The authors thank Dr. Ján Luha for help with the statistical analysis.

\section{Appendix}

Table A1. PSA1 RT-PCR health crosstabulation

\begin{tabular}{|c|c|c|c|c|c|}
\hline & & & \multicolumn{2}{|c|}{ health2 } & \multirow{2}{*}{ Total } \\
\hline & & & 1 good & $2 \mathrm{bad}$ & \\
\hline \multirow{6}{*}{$\begin{array}{l}\text { PSA1 } \\
\text { RT-PCR }\end{array}$} & \multirow{5}{*}{0 negat } & Count & 14 & 5 & 19 \\
\hline & & $\begin{array}{l}\text { \% within PSA1 } \\
\text { RT-PCR }\end{array}$ & $73.7 \%$ & $26.3 \%$ & $100.0 \%$ \\
\hline & & $\%$ within health & $93.3 \%$ & $38.5 \%$ & $67.9 \%$ \\
\hline & & Adjusted residual & 3.1 & -3.1 & - \\
\hline & & Count & 1 & 8 & 9 \\
\hline & \multirow[t]{6}{*}{1 posit } & $\begin{array}{l}\% \text { within PSA1 } \\
\text { RT-PCR }\end{array}$ & $11.1 \%$ & $88.9 \%$ & $100.0 \%$ \\
\hline \multirow{5}{*}{ Total } & & $\%$ within health & $6.7 \%$ & $61.5 \%$ & $32.1 \%$ \\
\hline & & Adjusted residual & -3.1 & 3.1 & - \\
\hline & & Count & 15 & 13 & 28 \\
\hline & & $\begin{array}{l}\text { \% within PSA1 } \\
\text { RT-PCR }\end{array}$ & $53.6 \%$ & $46.4 \%$ & $100.0 \%$ \\
\hline & & $\%$ within health & $100.0 \%$ & $100.0 \%$ & $100.0 \%$ \\
\hline
\end{tabular}

Chi-Square Tests

\begin{tabular}{|c|c|c|c|c|c|c|}
\hline & Value & $\mathrm{df}$ & $\begin{array}{l}\text { Asymp. } \\
\text { Sig. (2- } \\
\text { sided) }\end{array}$ & $\begin{array}{c}\text { Exact } \\
\text { Sig. (2- } \\
\text { sided) }\end{array}$ & $\begin{array}{c}\text { Exact } \\
\text { Sig. (1- } \\
\text { sided) }\end{array}$ & $\begin{array}{c}\text { Point } \\
\text { Proba- } \\
\text { bility }\end{array}$ \\
\hline $\begin{array}{l}\text { Pearson } \\
\text { Chi-Square }\end{array}$ & $9.614^{b}$ & 1 & .002 & .004 & .003 & - \\
\hline $\begin{array}{l}\text { Continuity } \\
\text { correction }^{\mathrm{a}}\end{array}$ & 7.263 & 1 & .007 & - & - & - \\
\hline $\begin{array}{l}\text { Likelihood } \\
\text { ratio }\end{array}$ & 10.494 & 1 & .001 & .004 & .003 & - \\
\hline $\begin{array}{l}\text { Fisher's exact } \\
\text { test }\end{array}$ & - & - & - & .004 & .003 & - \\
\hline $\begin{array}{l}\text { Linear-by- } \\
\text { linear } \\
\text { association }\end{array}$ & $9.270^{\mathrm{c}}$ & 1 & .002 & .004 & .003 & .003 \\
\hline $\begin{array}{l}\mathrm{N} \text { of valid } \\
\text { cases }\end{array}$ & 28 & - & - & - & - & - \\
\hline
\end{tabular}


Table A2. PSM1 RT-PCR health crosstabulation

\begin{tabular}{|c|c|c|c|c|c|}
\hline & & & \multicolumn{2}{|c|}{ health2 } & \multirow{2}{*}{ Total } \\
\hline & & & 1 good & $2 \mathrm{bad}$ & \\
\hline \multirow{8}{*}{$\begin{array}{l}\text { PSM1 } \\
\text { RT-PCR }\end{array}$} & \multirow{5}{*}{0 negat } & Count & 11 & 2 & 13 \\
\hline & & $\begin{array}{l}\text { \% within PSM1 } \\
\text { RT-PCR }\end{array}$ & $84.6 \%$ & $15.4 \%$ & $100.0 \%$ \\
\hline & & \% within health & $73.3 \%$ & $15.4 \%$ & $46.4 \%$ \\
\hline & & Adjusted residual & 3.1 & -3.1 & - \\
\hline & & Count & 4 & 11 & 15 \\
\hline & \multirow{3}{*}{1 posit } & $\begin{array}{l}\text { \% within PSM1 } \\
\text { RT-PCR }\end{array}$ & $26.7 \%$ & $73.3 \%$ & $100.0 \%$ \\
\hline & & $\%$ within health & $26.7 \%$ & $84.6 \%$ & $53.6 \%$ \\
\hline & & Adjusted residual & -3.1 & 3.1 & - \\
\hline \multirow{3}{*}{ Total } & & Count & 15 & 13 & 28 \\
\hline & & $\begin{array}{l}\text { \% within PSM1 } \\
\text { RT-PCR }\end{array}$ & $53.6 \%$ & $46.4 \%$ & $100.0 \%$ \\
\hline & & $\%$ within health & $100.0 \%$ & $100.0 \%$ & $100.0 \%$ \\
\hline
\end{tabular}

Table A3. PSA1 + PSM1 RT-PCR health crosstabulation

\begin{tabular}{|c|c|c|c|c|c|}
\hline & & & \multicolumn{2}{|c|}{ health2 } & \multirow{2}{*}{ Total } \\
\hline & & & 1 good & $2 \mathrm{bad}$ & \\
\hline \multirow{8}{*}{$\begin{array}{l}\text { PSA1- } \\
\text { PSM1 }\end{array}$} & \multirow{5}{*}{0 negat } & Count & 11 & 2 & 13 \\
\hline & & $\begin{array}{l}\text { \% within PSA1- } \\
\text { PSM1 }\end{array}$ & $84.6 \%$ & $15.4 \%$ & $100.0 \%$ \\
\hline & & $\%$ within health & $73.3 \%$ & $15.4 \%$ & $46.4 \%$ \\
\hline & & Adjusted residual & 3.1 & -3.1 & - \\
\hline & & Count & 4 & 11 & 15 \\
\hline & \multirow{6}{*}{$\begin{array}{l}\text { PSA1 } \\
\text { or } \\
\text { PSM1 } \\
\text { posit. }\end{array}$} & $\begin{array}{l}\% \text { within PSA1- } \\
\text { PSM1 }\end{array}$ & $26.7 \%$ & $73.3 \%$ & $100.0 \%$ \\
\hline & & $\%$ within health & $26.7 \%$ & $84.6 \%$ & $53.6 \%$ \\
\hline & & Adjusted residual & -3.1 & 3.1 & - \\
\hline \multirow{3}{*}{ Total } & & Count & 15 & 13 & 28 \\
\hline & & $\begin{array}{l}\text { \% within PSA1- } \\
\text { PSM1 }\end{array}$ & $53.6 \%$ & $46.4 \%$ & $100.0 \%$ \\
\hline & & $\%$ within health & $100.0 \%$ & $100.0 \%$ & $100.0 \%$ \\
\hline
\end{tabular}

Chi-Square Tests

\begin{tabular}{|c|c|c|c|c|c|c|}
\hline & Value & $\mathrm{df}$ & $\begin{array}{l}\text { Asymp. } \\
\text { Sig. (2- } \\
\text { sided) }\end{array}$ & $\begin{array}{l}\text { Exact } \\
\text { Sig. }(2- \\
\text { sided) }\end{array}$ & $\begin{array}{l}\text { Exact } \\
\text { Sig. (1- } \\
\text { sided) }\end{array}$ & $\begin{array}{c}\text { Point } \\
\text { Proba- } \\
\text { bility }\end{array}$ \\
\hline $\begin{array}{l}\text { Pearson } \\
\text { Chi-Square }\end{array}$ & $9.403^{b}$ & 1 & .002 & .003 & .003 & - \\
\hline $\begin{array}{l}\text { Continuity } \\
\text { correction }^{\mathrm{a}}\end{array}$ & 7.217 & 1 & .007 & - & - & - \\
\hline $\begin{array}{l}\text { Likelihood } \\
\text { ratio }\end{array}$ & 10.113 & 1 & .001 & .003 & .003 & - \\
\hline $\begin{array}{l}\text { Fisher's exact } \\
\text { test }\end{array}$ & - & - & - & .003 & .003 & - \\
\hline $\begin{array}{l}\text { Linear-by- } \\
\text { linear } \\
\text { association }\end{array}$ & $9.067^{c}$ & 1 & .003 & .003 & .003 & .003 \\
\hline $\begin{array}{l}\mathrm{N} \text { of valid } \\
\text { cases }\end{array}$ & 28 & - & - & - & - & - \\
\hline
\end{tabular}

Chi-Square Tests

\begin{tabular}{|c|c|c|c|c|c|c|}
\hline & Value & $\mathrm{df}$ & $\begin{array}{l}\text { Asymp. } \\
\text { Sig. (2- } \\
\text { sided) }\end{array}$ & $\begin{array}{l}\text { Exact } \\
\text { Sig. (2- } \\
\text { sided) }\end{array}$ & $\begin{array}{l}\text { Exact } \\
\text { Sig. (1- } \\
\text { sided) }\end{array}$ & $\begin{array}{c}\text { Point } \\
\text { Proba- } \\
\text { bility }\end{array}$ \\
\hline $\begin{array}{l}\text { Pearson } \\
\text { Chi-Square }\end{array}$ & $9.403^{b}$ & 1 & .002 & .003 & .003 & - \\
\hline $\begin{array}{l}\text { Continuity } \\
\text { correction }^{\mathrm{a}}\end{array}$ & 7.217 & 1 & .007 & - & - & - \\
\hline $\begin{array}{l}\text { Likelihood } \\
\text { ratio }\end{array}$ & 10.113 & 1 & .001 & .003 & .003 & - \\
\hline $\begin{array}{l}\text { Fisher's exact } \\
\text { test }\end{array}$ & - & - & - & .003 & .003 & - \\
\hline $\begin{array}{l}\text { Linear-by- } \\
\text { linear } \\
\text { association }\end{array}$ & $9.067^{c}$ & 1 & .003 & .003 & .003 & .003 \\
\hline $\begin{array}{l}\mathrm{N} \text { of valid } \\
\text { cases }\end{array}$ & 28 & - & - & - & - & - \\
\hline
\end{tabular}


Table A4. PSA2 RT-PCR health crosstabulation

\begin{tabular}{|c|c|c|c|c|c|}
\hline & & & \multicolumn{2}{|c|}{ health2 } & \multirow{2}{*}{ Total } \\
\hline & & & 1 good & $2 \mathrm{bad}$ & \\
\hline \multirow{8}{*}{$\begin{array}{l}\text { PSA2 } \\
\text { RT-PCR }\end{array}$} & \multirow{5}{*}{0 negat } & Count & 12 & 5 & 17 \\
\hline & & $\begin{array}{l}\% \text { within PSA2 } \\
\text { RT-PCR }\end{array}$ & $70.6 \%$ & $29.4 \%$ & $100.0 \%$ \\
\hline & & $\%$ within health & $80.0 \%$ & $38.5 \%$ & $60.7 \%$ \\
\hline & & Adjusted residual & 2.2 & -2.2 & - \\
\hline & & Count & 3 & 8 & 11 \\
\hline & \multirow[t]{3}{*}{1 posit } & $\begin{array}{l}\% \text { within PSA2 } \\
\text { RT-PCR }\end{array}$ & $27.3 \%$ & $72.7 \%$ & $100.0 \%$ \\
\hline & & $\%$ within health & $20.0 \%$ & $61.5 \%$ & $39.3 \%$ \\
\hline & & Adjusted residual & -2.2 & 2.2 & - \\
\hline \multirow{3}{*}{ Total } & & Count & 15 & 13 & 28 \\
\hline & & $\begin{array}{l}\% \text { within PSA2 } \\
\text { RT-PCR }\end{array}$ & $53.6 \%$ & $46.4 \%$ & $100.0 \%$ \\
\hline & & $\%$ within health & $100.0 \%$ & $100.0 \%$ & $100.0 \%$ \\
\hline
\end{tabular}

Table A5. PSM2 RT-PCR health crosstabulation

\begin{tabular}{|c|c|c|c|c|c|}
\hline & & & \multicolumn{2}{|c|}{ health2 } & \multirow{2}{*}{ Total } \\
\hline & & & 1 good & $2 \mathrm{bad}$ & \\
\hline \multirow{8}{*}{$\begin{array}{l}\text { PSM2 } \\
\text { RT-PCR }\end{array}$} & \multirow{5}{*}{0 negat } & Count & 13 & 0 & 13 \\
\hline & & $\begin{array}{l}\text { \% within PSM2 } \\
\text { RT-PCR }\end{array}$ & $100.0 \%$ & $.0 \%$ & $100.0 \%$ \\
\hline & & $\%$ within health & $86.7 \%$ & $.0 \%$ & $46.4 \%$ \\
\hline & & Adjusted residual & 4.6 & -4.6 & - \\
\hline & & Count & 2 & 13 & 15 \\
\hline & \multirow[t]{3}{*}{1 posit } & $\begin{array}{l}\text { \% within PSM2 } \\
\text { RT-PCR }\end{array}$ & $13.3 \%$ & $86.7 \%$ & $100.0 \%$ \\
\hline & & $\%$ within health & $13.3 \%$ & $100.0 \%$ & $53.6 \%$ \\
\hline & & Adjusted residual & -4.6 & 4.6 & - \\
\hline \multirow{3}{*}{ Total } & & Count & 15 & 13 & 28 \\
\hline & & $\begin{array}{l}\% \text { within PSM2 } \\
\text { RT-PCR }\end{array}$ & $53.6 \%$ & $46.4 \%$ & $100.0 \%$ \\
\hline & & $\%$ within health & $100.0 \%$ & $100.0 \%$ & $100.0 \%$ \\
\hline
\end{tabular}

Chi-Square Tests

\begin{tabular}{|c|c|c|c|c|c|c|}
\hline & Value & df & $\begin{array}{l}\text { Asymp. } \\
\text { Sig. (2- } \\
\text { sided) }\end{array}$ & $\begin{array}{l}\text { Exact } \\
\text { Sig. (2- } \\
\text { sided) }\end{array}$ & $\begin{array}{l}\text { Exact } \\
\text { Sig. (1- } \\
\text { sided) }\end{array}$ & $\begin{array}{l}\text { Point } \\
\text { Prob- } \\
\text { ability }\end{array}$ \\
\hline $\begin{array}{l}\text { Pearson } \\
\text { Chi-Square }\end{array}$ & $5.038^{b}$ & 1 & .025 & .051 & .031 & - \\
\hline $\begin{array}{l}\text { Continuity } \\
\text { correction }^{\mathrm{a}}\end{array}$ & 3.447 & 1 & .063 & - & - & - \\
\hline $\begin{array}{l}\text { Likelihood } \\
\text { ratio }\end{array}$ & 5.185 & 1 & .023 & .051 & .031 & - \\
\hline $\begin{array}{l}\text { Fisher's exact } \\
\text { test }\end{array}$ & - & - & - & .051 & .031 & - \\
\hline $\begin{array}{l}\text { Linear-by- } \\
\text { linear } \\
\text { association }\end{array}$ & $4.858^{\mathrm{c}}$ & 1 & .028 & .051 & .031 & .027 \\
\hline $\begin{array}{l}\mathrm{N} \text { of valid } \\
\text { cases }\end{array}$ & 28 & - & - & - & - & - \\
\hline
\end{tabular}

Chi-Square Tests

\begin{tabular}{|c|c|c|c|c|c|c|}
\hline & Value & $\mathrm{df}$ & $\begin{array}{l}\text { Asymp. } \\
\text { Sig. (2- } \\
\text { sided) }\end{array}$ & $\begin{array}{l}\text { Exact } \\
\text { Sig. }(2- \\
\text { sided) }\end{array}$ & $\begin{array}{l}\text { Exact } \\
\text { Sig. (1- } \\
\text { sided) }\end{array}$ & $\begin{array}{l}\text { Point } \\
\text { Prob- } \\
\text { ability }\end{array}$ \\
\hline $\begin{array}{l}\text { Pearson } \\
\text { Chi-Square }\end{array}$ & $21.031^{\mathrm{b}}$ & 1 & .000 & .000 & .000 & - \\
\hline $\begin{array}{l}\text { Continuity } \\
\text { correction }^{\mathrm{a}}\end{array}$ & 17.691 & 1 & .000 & - & - & - \\
\hline $\begin{array}{l}\text { Likelihood } \\
\text { ratio }\end{array}$ & 26.893 & 1 & .000 & .000 & .000 & - \\
\hline $\begin{array}{l}\text { Fisher's exact } \\
\text { test }\end{array}$ & - & - & - & .000 & .000 & - \\
\hline $\begin{array}{l}\text { Linear-by- } \\
\text { linear } \\
\text { association }\end{array}$ & $20.280^{c}$ & 1 & .000 & .000 & .000 & .000 \\
\hline $\begin{array}{l}\mathrm{N} \text { of valid } \\
\text { cases }\end{array}$ & 28 & - & - & - & - & - \\
\hline
\end{tabular}


Table A6. PSA2+PSM2 RT-PCR health crosstabulation

\begin{tabular}{|c|c|c|c|c|c|}
\hline & & & \multicolumn{2}{|c|}{ health2 } & \multirow{2}{*}{$\begin{array}{l}\text { Total } \\
1 \text { good }\end{array}$} \\
\hline & & & 1 good & $2 \mathrm{bad}$ & \\
\hline \multirow{8}{*}{$\begin{array}{l}\text { PSA2- } \\
\text { PSM2 }\end{array}$} & \multirow{5}{*}{0 neg } & Count & 11 & 0 & 11 \\
\hline & & $\begin{array}{l}\text { \% within PSA2- } \\
\text { PSM2 }\end{array}$ & $100.0 \%$ & $.0 \%$ & $100.0 \%$ \\
\hline & & $\%$ within health & $73.3 \%$ & $.0 \%$ & $39.3 \%$ \\
\hline & & Adjusted residual & 4.0 & -4.0 & - \\
\hline & & Count & 4 & 13 & 17 \\
\hline & \multirow{6}{*}{$\begin{array}{l}\text { PSA2 } \\
\text { or } \\
\text { PSM2 } \\
\text { posit. }\end{array}$} & $\begin{array}{l}\% \text { within PSA2- } \\
\text { PSM2 }\end{array}$ & $23.5 \%$ & $76.5 \%$ & $100.0 \%$ \\
\hline & & $\%$ within health & $26.7 \%$ & $100.0 \%$ & $60.7 \%$ \\
\hline & & Adjusted residual & -4.0 & 4.0 & - \\
\hline \multirow{3}{*}{ Total } & & Count & 15 & 13 & 28 \\
\hline & & $\begin{array}{l}\% \text { within PSA2- } \\
\text { PSM2 }\end{array}$ & $53.6 \%$ & $46.4 \%$ & $100.0 \%$ \\
\hline & & $\%$ within health & $100.0 \%$ & $100.0 \%$ & $100.0 \%$ \\
\hline
\end{tabular}

Table A7. PSA antigen 1 year after RP health crosstabulation

\begin{tabular}{|c|c|c|c|c|c|}
\hline & & & \multicolumn{2}{|c|}{ health2 } & \multirow{2}{*}{ Total } \\
\hline & & & 1 good & $2 \mathrm{bad}$ & \\
\hline \multirow{8}{*}{$\begin{array}{l}\text { PSA } \\
\text { antigen- } \\
1 \text { year } \\
\text { after RP }\end{array}$} & \multirow{5}{*}{$\begin{array}{l}0 \\
\text { less } \\
\text { than } \\
0.2\end{array}$} & Count & 15 & 7 & 22 \\
\hline & & $\begin{array}{l}\% \text { within PSA } \\
\text { antigen } 1\end{array}$ & $68.2 \%$ & $31.8 \%$ & $100.0 \%$ \\
\hline & & $\%$ within health & $100.0 \%$ & $53.8 \%$ & $78.6 \%$ \\
\hline & & Adjusted residual & 3.0 & -3.0 & - \\
\hline & & Count & 0 & 6 & 6 \\
\hline & \multirow{6}{*}{$\begin{array}{l}1 \\
0.2 \\
\text { and } \\
\text { more }\end{array}$} & $\begin{array}{l}\% \text { within PSA } \\
\text { antigen } 1\end{array}$ & $.0 \%$ & $100.0 \%$ & $100.0 \%$ \\
\hline & & $\%$ within health & $.0 \%$ & $46.2 \%$ & $21.4 \%$ \\
\hline & & Adjusted residual & -3.0 & 3.0 & - \\
\hline \multirow{3}{*}{ Total } & & Count & 15 & 13 & 28 \\
\hline & & $\begin{array}{l}\% \text { within PSA } \\
\text { antigen } 1\end{array}$ & $53.6 \%$ & $46.4 \%$ & $100.0 \%$ \\
\hline & & $\%$ within health & $100.0 \%$ & $100.0 \%$ & $100.0 \%$ \\
\hline
\end{tabular}

Chi-Square Tests

\begin{tabular}{|c|c|c|c|c|c|c|}
\hline & Value & $\mathrm{df}$ & $\begin{array}{l}\text { Asymp. } \\
\text { Sig. (2- } \\
\text { sided) }\end{array}$ & $\begin{array}{l}\text { Exact } \\
\text { Sig. (2- } \\
\text { sided) }\end{array}$ & $\begin{array}{l}\text { Exact } \\
\text { Sig. (1- } \\
\text { sided) }\end{array}$ & $\begin{array}{l}\text { Point } \\
\text { Prob- } \\
\text { ability }\end{array}$ \\
\hline $\begin{array}{l}\text { Pearson } \\
\text { Chi-Square }\end{array}$ & $15.702^{\mathrm{b}}$ & 1 & .000 & .000 & .000 & - \\
\hline $\begin{array}{l}\text { Continuity } \\
\text { correction }^{\mathrm{a}}\end{array}$ & 12.778 & 1 & .000 & - & - & - \\
\hline $\begin{array}{l}\text { Likelihood } \\
\text { ratio }\end{array}$ & 20.123 & 1 & .000 & .000 & .000 & - \\
\hline $\begin{array}{l}\text { Fisher's exact } \\
\text { test }\end{array}$ & - & - & - & .000 & .000 & - \\
\hline $\begin{array}{l}\text { Linear-by- } \\
\text { linear } \\
\text { association }\end{array}$ & $15.141^{\mathrm{c}}$ & 1 & .000 & .000 & .000 & .000 \\
\hline $\begin{array}{l}\mathrm{N} \text { of valid } \\
\text { cases }\end{array}$ & 28 & - & - & - & - & - \\
\hline
\end{tabular}

Chi-Square Tests

\begin{tabular}{|c|c|c|c|c|c|c|}
\hline & Value & $\mathrm{df}$ & $\begin{array}{l}\text { Asymp. } \\
\text { Sig. (2- } \\
\text { sided) }\end{array}$ & $\begin{array}{l}\text { Exact } \\
\text { Sig. (2- } \\
\text { sided) }\end{array}$ & $\begin{array}{l}\text { Exact } \\
\text { Sig. (1- } \\
\text { sided) }\end{array}$ & $\begin{array}{l}\text { Point } \\
\text { Prob- } \\
\text { ability }\end{array}$ \\
\hline $\begin{array}{l}\text { Pearson } \\
\text { Chi-Square }\end{array}$ & $8.811^{b}$ & 1 & .003 & .005 & .005 & - \\
\hline $\begin{array}{l}\text { Continuity } \\
\text { correction }^{\text {a }}\end{array}$ & 6.283 & 1 & .012 & - & - & - \\
\hline $\begin{array}{l}\text { Likelihood } \\
\text { ratio }\end{array}$ & 11.152 & 1 & .001 & .005 & .005 & - \\
\hline $\begin{array}{l}\text { Fisher's exact } \\
\text { test }\end{array}$ & - & - & - & .005 & .005 & - \\
\hline $\begin{array}{l}\text { Linear-by- } \\
\text { linear } \\
\text { association }\end{array}$ & $8.497^{c}$ & 1 & .004 & .005 & .005 & .005 \\
\hline $\begin{array}{l}\mathrm{N} \text { of valid } \\
\text { cases }\end{array}$ & 28 & - & - & - & - & - \\
\hline
\end{tabular}


Table A8. PSA antigen 2 years after RP health crosstabulation

\begin{tabular}{|c|c|c|c|c|c|}
\hline & & & health2 & & \\
\hline & & & 1 good & $2 \mathrm{bad}$ & \\
\hline \multirow{8}{*}{$\begin{array}{l}\text { PSA } \\
\text { antigen } \\
2 \text { years } \\
\text { after RP }\end{array}$} & \multirow{5}{*}{$\begin{array}{l}0 \\
\text { less } \\
\text { than } \\
0.2\end{array}$} & Count & 15 & 5 & 20 \\
\hline & & $\begin{array}{l}\% \text { within PSA } \\
\text { antigen } 2\end{array}$ & $75.0 \%$ & $25.0 \%$ & $100.0 \%$ \\
\hline & & $\%$ within health & $100.0 \%$ & $38.5 \%$ & $71.4 \%$ \\
\hline & & Adjusted residual & 3.6 & -3.6 & - \\
\hline & & Count & 0 & 8 & 8 \\
\hline & \multirow{6}{*}{$\begin{array}{l}1 \\
0.2 \\
\text { and } \\
\text { more }\end{array}$} & $\begin{array}{l}\% \text { within PSA } \\
\text { antigen } 2\end{array}$ & $.0 \%$ & $100.0 \%$ & $100.0 \%$ \\
\hline & & $\%$ within health & $.0 \%$ & $61.5 \%$ & $28.6 \%$ \\
\hline & & Adjusted residual & -3.6 & 3.6 & - \\
\hline \multirow{3}{*}{ Total } & & Count & 15 & 13 & 28 \\
\hline & & $\begin{array}{l}\% \text { within PSA } \\
\text { antigen } 2\end{array}$ & $53.6 \%$ & $46.4 \%$ & $100.0 \%$ \\
\hline & & $\%$ within health & $100.0 \%$ & $100.0 \%$ & $100.0 \%$ \\
\hline
\end{tabular}

\section{References}

Altimari A., Grigioni A., Benedettini E., Gabusi E., Schiavina R., Martinell A., Morselli-Labate A., Martorana G., Grigioni W., Fiorentino M. (2008): Diagnostic role of circulating free plasma DNA detection in patients with localized prostate cancer. Am. J. Clin. Pathol. 129, 756-762; doi:10.1309/DBPX1MFNDDJBW1FL

Baffa R., Moreno J. G., Monne M., Veronese L., Gomella L. G. (1996): A comparative analysis of prostate-specific antigen gene sequence in benign and malignant prostate tissue. Urology 47, 795-800; doi:10.1016/S00904295(96)00060-X

Boccon-Gibod L., Djavan W. B., Hammerer P., Hoeltl W., Kattan M. W., Prayer-Galetti T., Teillac P., Tunn U. W. (2004): Management of prostate-specific antigen relapse in prostate cancer: a European Consensus. Int. J. Clin. Pract. 58, 382-390; doi:10.1111/j.1368-5031.2004.00184.x

Boyle P., Ferlay J. (2005): Cancer incidence and mortality in Europe 2004. Ann. Oncol. 16, 481-488; doi:10.1093/annonc/ mdi098

Brawer M. K., Chetner M. P., Beatie J., Buchner D. M., Vessella R. L., Lange P. H. (1992): Screening for prostatic carcinoma with prostate specific antigen. J. Urol. 147, 841-845

Fletcher C. D. M. (2007): Histology of Tumors. (Vol. 1, 3rd edition), Churchill Livingstone Elsevier, Philadelphia

Gala J. L., Heusterspreute M., Loric S., Hanon F., Tombal B., Van Cangh P., De Nayer P., Philippe M. (1998): Expression of prostate-specific antigen and prostate-specific membrane antigen transcripts in blood cells: implications for the
Chi-Square Tests

\begin{tabular}{|c|c|c|c|c|c|c|}
\hline & Value & $\mathrm{df}$ & $\begin{array}{l}\text { Asymp. } \\
\text { Sig. (2- } \\
\text { sided) }\end{array}$ & $\begin{array}{l}\text { Exact } \\
\text { Sig. (2- } \\
\text { sided) }\end{array}$ & $\begin{array}{l}\text { Exact } \\
\text { Sig. (1- } \\
\text { sided) }\end{array}$ & $\begin{array}{l}\text { Point } \\
\text { Prob- } \\
\text { ability }\end{array}$ \\
\hline $\begin{array}{l}\text { Pearson } \\
\text { Chi-Square }\end{array}$ & & 1 & .000 & .000 & .000 & - \\
\hline $\begin{array}{l}\text { Continuity } \\
\text { correction }^{\mathrm{a}}\end{array}$ & 10.084 & 1 & .001 & - & - & - \\
\hline $\begin{array}{l}\text { Likelihood } \\
\text { ratio }\end{array}$ & 16.180 & 1 & .000 & .000 & .000 & - \\
\hline $\begin{array}{l}\text { Fisher's exact } \\
\text { test }\end{array}$ & - & - & - & .000 & .000 & - \\
\hline $\begin{array}{l}\text { Linear-by- } \\
\text { linear } \\
\text { association }\end{array}$ & & 1 & .000 & .000 & .000 & .000 \\
\hline $\begin{array}{l}\mathrm{N} \text { of valid } \\
\text { cases }\end{array}$ & 28 & - & - & - & - & - \\
\hline
\end{tabular}

detection of hematogenous prostate cells and standardization. Clin. Chem. 44, 472-481

Ghossein R. A., Scher H. I., Gerald W. L., Kelly W. K., Curley T., Amsterdam A. (1995): Detecting of circulating tumor cells in patients with localized and metastatic prostatic carcinoma: clinical implications. J. Clin. Oncol. 13, 1195-1200

Haas C. J., Wagner T., Wawroschek F., Arnholdt H. (2005): Combined application of RT-PCR and immunohistochemistry on paraffin embedded sentinel lymph nodes of prostate cancer patients. Pathol. Res. Pract. 200, 763-770; doi:10.1016/j.prp.2004.09.008

Chang S. S., Benson M. C., Campbell S. C, Crook J., Dreicer R., Evans Ch. P., Hall M. C., Higano C., Kelly W. K., Sartor O., Smith J. A. Jr. (2005): Society of Urologic Oncology position statement: Redefining the management of hormone-refractory prostate carcinoma. Cancer 103, 11-21; doi:10.1002/cncr.20726

Jemal A., Siegel R., Ward E., Hao Y., Xu J., Murray T., Thun M. J. (2008): Cancer statistics, 2008. CA Cancer. J. Clin. 58, 71-96; doi:10.3322/CA.2007.0010

Kataja V. V., Bergh J. (2005): ESMO Minimum Clinical Recommendations for diagnosis, treatment and follow-up of prostate cancer. Ann. Oncol. 16, 34-36; doi:10.1093/annonc/mdi826

Katz A. E., Olsson C. A., Raffo A. J., Cama C., Perlam H., Seaman E. (1994): Molecular staging of prostate cancer with the use of an enhanced reverse transcriptase - PCR assay. Urology 43, 765-775; doi:10.1016/0090-4295(94)90132-5

Kolombo I., Poršová M., Zemanová I., Horecký M., Antonová P., Vlásek T. (2007): Prostatic specific antigen (PSA) 
- situation in the year 2007. Onkológia 2, 357-362 (in Slovak)

Kumar V., Abbas A. K., Fausto N., Mitchell R. (2007): Robbins Basic Pathology. Eight edition. Saunders Elsevier, Philadelphia

Moul J. W. (2000): Prostate specific antigen only progresion of prostate cancer. J. Urol. 163, 1632-1642; doi:10.1016/ S0022-5347(05)67511-8

Narita D., Raica M., Anghel A., Suciu C., Cimpean A. (2005): Immunohistochemical localization of prostate-specific antigen in benign and malignant breast conditions. Rom. J. Morphol. Embryol. 46, 41-45

Narita D., Anghel A., Motoc M. (2008): Prostate-specific antigen may serve as a pathological predictor in breast cancer. Rom. J. Morphol. Embryol. 49, 173-180

Parkin D. M., Bray F. I., Devesa S. S. (2001): Cancer burden in the year 2000: the global picture. Eur. J. Cancer 37, S4-66 doi:10.1016/S0959-8049(01)00267-2

Repiská V., Mikloši M., Zummerová A., Danišovič L., Hoffmann J., Breza J. (2005): Detection of circulating tumor cells in patients with prostate cancer. Biologia 60, 703-709

Rubin R., Farber J. L. (1999): Pathology. Third edition, J. B. Lippincott Company, Philadelphia

Rubin R., Strayer D. (2007): Rubin's Pathology, Clinicopathologic Foundations of Medicine. Fifth edition, Lippincott Williams \& Wilkins, Philadelphia

Underwood J. C., Cross S. (2009): General and Systematic Pathology. Fifth edition, Churchill Livingstone, Edinburgh

Zhang L., Wang C. Y., Yang R., Shi J., Fu R., Chen L., Klocker H., Zhang J. (2008): Real time quantitative RT-PCR assay of prostate-specific antigen and prostate-specific membrane antigen in peripheral blood for detection of prostate cancer micrometastasis. Urol. Oncol. 26, 634-640; doi:10.1016/j.urolonc.2007.07.016

Received: March 17, 2010

Final version accepted: July 1, 2010 